\title{
Nature, genetics and the Niven factor
}

\section{Kevin Davies, the founding editor of Nature Genetics, recalls the perfect storm of events and personalities that governed the launch of the journal 15 years ago and its formative years. The journal offered a high-profile forum for the genetics community - and a bold new direction for Nature Publishing Group.}

"Look, it's a great idea, but if you're going to do this, you should make it the best possible journal it can be, even competing with Nature if necessary."

-Eric Lander (October 1991)

ntering Nature's London headquarters, just off Fleet Street, as a newly hired assistant editor in 1990, I initially thought I'd entered the wrong building. This was no bastion of high-tech science publishing. Battered desks were crammed into every nook and cranny, disheveled reporters and haggard editors were buried under piles of newspapers and magazines, and the staff were typing on ridiculously cheap plastic electronic typewriters.

Things were slightly better in Nature's Washington, D.C. bureau —at least we had PCs—-where I was assigned with primary responsibility for handling papers on human and mammalian genetics. Many wonderful manuscripts arrived in my inbox: the identification of the male sex-determining gene (Peter Goodfellow and Robin Lovell-Badge), the characterization of expanding triplet repeats and Hunt Willard's cloning of XIST, to name but a few. But there were many other first-rate papers that, after occasionally testy transatlantic debate with my fellow editors, were turned away, often without review. Authors received the familiar letter explaining that their work was deemed "not of sufficient general interest."

Two examples stick firmly in my mind. Christine van Broeckhoven's report of an interstitial duplication on chromosome 17 associated with Charcot-Marie-Tooth disease was rejected because she hadn't identified the specific gene(s) involved. She resubmitted to a specialist journal, but her paper was still under review months later when, much to my dismay, Cell published an almost identical report from Jim Lupski's team at Baylor. I wonder whatever happened to copy number variants!

Another striking example occurred in 1991, when Teepu Siddique, Bob Horvitz and colleagues tracked the gene for familial amyotrophic lateral sclerosis (ALS) to chromosome 21. To my mind, a major breakthrough in unraveling the genetics of Lou Gehrig's disease had to be of 'general interest'-I could easily imag- ine the front-page headlines in the New York Times. But coming in the wake of the embarrassing retraction of several highly publicized psychiatric linkage papers (schizophrenia on chromosome 5 , anyone?), my colleagues opted to reject the paper without peer review. It was subsequently snapped up by the New England Journal of Medicine.

The then editor of Nature, John Maddox, whose presence in the London office was evident by the pall of cigarette smoke billowing from his corner cubicle, frequently enjoyed thumbing through stacks of rejected manuscripts to see what Nature was turning away. In particular, the ALS rejection perplexed him. "We are, after all, in the publishing business," he reminded the biology team, and exhorted us to always consider the broader public interest in our decisions. He even coined a name for it— "the David Niven factor"- - after the debonair British actor who had died of the disease. Of course, Nature was never intended to be the forum for publishing mundane mendelian linkage papers, but we smartly heeded the boss's advice, and at least one more was published following his intervention: the mapping of the gene for Werner syndrome. More importantly, however, Maddox had highlighted the quality of many genetics papers that Nature couldn't accommodate - and the tantalizing possibilities, should we seek to publish more of them.

In the summer of 1991, Nature's chief biology editor, Miranda Robertson, and publishing director, Mary Waltham, began discussing the prospects of some sort of spin-off publication. It was a risky proposition: few people had fond memories of (or could understand the rationale for) Nature New Biology, the ill-fated experiment in the early 1970s when Nature splintered into three weekly issues. That experiment was abruptly halted in 1974-the same year that a young Nature editor named Benjamin Lewin headed to the US and launched a journal devoted to "the biology of cells and their viruses," which quickly became Nature's nemesis-Cell.

But what field should this new sister journal cover? Some of the biology team worried that a new journal in their pet field would dilute the papers in immunology or neuroscience in Nature itself. I had no such concerns, and the launch of the Human Genome Project didn't hurt, either. But as I pitched the idea to several 
prominent geneticists, I was dismayed to learn that at least two publishers were exploring a similar venture: Hunt Willard and my former $\mathrm{PhD}$ advisor, Kay E. Davies (no relation), were launching a monthly journal through Oxford University Press called Human Molecular Genetics. Next, Haig Kazazian said that Wiley, too, was jumping on the bandwagon. He even had the temerity to suggest that Nature had missed the boat, although personally I didn't see the mass appeal of a journal entitled Human Mutation.

But researchers were clamoring for a high profile, rapid-publication alternative to Genomics and The American Journal of Human Genetics. Nature Genetics was sounding better and better, particularly with the enthusiastic backing of Nature's then Washington bureau chief and deputy editor, Barbara Culliton (who went on to launch Nature Medicine and run the Genome News Network at Celera). The clincher came in October 1991, when we invited a few geneticists to lunch during the American Society of Human Genetics conference in Washington, D.C. As I labored to explain how our new publication (and the community) would prosper from the referral of worthy but rejected manuscripts from Nature, one up-and-coming geneticist threw up his hands and said: "Look, it's a great idea, but if you're going to do this, you should make it the best possible journal it can be, even competing with Nature if necessary." It's possible his language was a little more colorful, but in any event, it would not be the last time we heard from one Eric Lander.

During Thanksgiving week, 1991, Maddox, Waltham, Robertson and I met in Manhattan to make the momentous decision. There would be no launch without the blessing of Nicholas Byam Shaw, Macmillan's urbane chairman, but he loved the plan. He issued just two vetoes - there would be no page charges and no editorial board - neither, he said, was part of the Nature tradition. Nature Genetics received the green light, with just four months to pull the first issue together.

The inaugural issue of Nature Genetics in April 1992 exceeded all our expectations, crammed with exciting papers from prestigious authors-Francis Collins, Bert Vogelstein, Grant Sutherland, Doug Wallace and J. Craig Venter, to name a few. The only intervention from Maddox came as we went to press, when he opted to write the inaugural editorial himself. It was a good decision-Maddox outlined the key areas the journal would target, and it is remarkable how well it has held up. (Not surprising, from the author of What Remains to be Discovered.)

After 12 months flying solo, Nature Genetics finally recruited its first assistant editor. Culliton and I arranged to interview Adrian Ivinson at the Oriental Club in London, only for a dumbfounded Culliton to be informed that club rules barred women from the library. We convened in a hallway and got our man. Ivinson thrived as assistant editor-although we were briefly threatened with a lawsuit following a typically strident editorial on the forensic genotyping of the last Tsar's remains — and would become publisher of the growing family of Nature sister journals.

Our first impact factor from the Institute of Scientific Information (ISI) proved that Nature Genetics was reaching an audience far beyond its modest early circulation. Indeed, for two consecutive years in the mid-1990s, Nature Genetics garnered the highest impact factor for any research journal in any discipline, topping Nature, Science and even Cell. We were flattered, but perplexed by how seriously international scientists took the results. European researchers could quote me the journal's latest impact factor to two decimal places, while labs I toured in Japan prominently displayed the latest ISI top ten rankings.

Relations with Nature were cordial enough, despite the occasional mishap. We were thrilled when Jean-Louis Mandel sent us his paper on the cloning of the gene for X-linked adrenoleukodystrophy (the disorder featured in the movie Lorenzo's Oil). Just as we were readying the acceptance letter, I received a call from a groveling Nature editor in London, stating that Nature had reversed its original decision and elected to publish the paper after Mandel's belated appeal. We even had the gratification of seeing a couple of our rejected papers end up in Cell, prompting momentary anxiety as to whether we'd made some catastrophic mistake.

The press naturally feasted on the 'Gene of the Month' fever that Nature Genetics helped to promote. Spinocerebellar ataxia, novelty seeking and hemochromatosis were just a few highlights. Heeding Maddox's advice and the "Niven factor," we occasionally published papers more for their undisputable general interest than their ostensible scientific advance. For example, we published the refined mapping of the gene for X-linked generalized hypertrichosis largely because of the fascinating hairy phenotype, not because the authors were close to finding the gene. This prompted angry letters from several aggrieved geneticists protesting our editorial decision. But a stunning story on hirsutism and atavistic mutations in the New York Times by Natalie Angier convinced me we'd done the right thing.

It was a privilege to help create something so thrilling and to interact with such a talented and vibrant community of geneticists-my principal reason for moving into science publishing in the first place. Those that have followed me since 1997—Barbara Cohen (now with PLoS), Bette Phimister (New England Journal of Medicine) and the current editorial team have done a superb job of broadening the journal's horizons, making it a must-read for a much wider community. The field of genetics moves at breathtaking pace, but Nature Genetics seems set to nurture those changes better than ever.

Links to papers mentioned in this Editorial can be found through Connotea (http://www.connotea.org/user/ngnomics/tag/ Niven\%20factor).

Kevin Davies is currently Editor-in-Chief of Bio-IT World. e-mail:kevin_davies@bio-itworld.com 